\title{
THE FIRST LANGUAGE INTERFERENCE TOWARD STUDENTS' ENGLISH SPEAKING AS FOREIGN LANGUAGE
}

\author{
TANIA SYAFUTRI \\ IAIN Bengkulu \\ taniajimin@yahoo.com \\ ANDRI SAPUTRA \\ IAIN Bengkulu
}

DOI: 10.29300/ling.v7i1.4327

Received: March 30 ${ }^{\text {th }}, 2021$

Accepted: June $9^{\text {th }}, 2021$

Published: July $14^{\text {th }}, 2021$

\begin{abstract}
This research aims at analyzing the first language interference toward students' English speaking as foreign language made by sixth semester students in course design subject, such as phonological interference (pronunciation), grammatical (morphological and lexical), and lexical interference (vocabulary), and the factors that caused interference of the first language. This research is descriptive qualitative. The findings of the research explained that students made three types of interference categorized as phonological interference such as pronounce the word incorrectly (vowel, diphthong, consonan, and allophonic variation), grammatical interference such as in morphological (singular-plural agreement) and syntactical (subject-verb agreement, phrase, comparative adjective, possessive adjective, and parallel structure), and lexical interference such as in vocabulary (combining between Indonesian and the English language). The data showed that students often make error in phonological aspect. The factors that caused first language interference are lack of knowledge, Indonesian transfer, and lack of vocabularies of foreign language that mastered by students or respondents.
\end{abstract}

Keywords: First language interference, Foreign language, English, speaking

\section{INTRODUCTION}

Indonesia consists of large ethnic groups with their own vernaculars living in wide area. The people in this country use Indonesian (Bahasa) as national language but there are many vernaculars which are used regionally from each ethnicity in every region in Indonesia (Aini, L., Wibowo, A., \& Sriningsih, M, 2015). Thus, when they try to learn English as second language or foreign language, they have some difficulties in mastering it and when they try to learn, they do some mistakes or errors in speaking English. The psychological aspect involves if the people who use first language or mother tongue as the old habit that make happens the interference in second language (Wood, W., \& Runger, D, 2015). While in sociolinguistic refers to the interaction use mother tongue in communities that influence how people speak in second language. Therefore, students or the people difficult in mastering the second language.

How to cite this article: Syafutri, T., \& Saputra, A. (2021). The First Language Interference toward Students' English Speaking as Foreign Language. Linguists : Journal Of Linguistics and Language Teaching, 7(1), 39-51. doi:http://dx.doi.org/10.29300/ling.v7i1.4327 
Weinrich stated the term interference of first language implies the rearrangement of patterns that result from the introduction if foreign elements into the more highly structure domains of language, such as a large part of the phonemic system morphology and syntax, and certain vocabulary areas (kinship, colour, weather, etc) (Weinreich, U. 1953).

One of the skills which most influenced by first language is speaking. Speaking is one of English skills that have a function in communication to deliver what speaker means and to communicate with each other. According to Richards, we should master speaking skill in English as our priority, because with speaking we can communicate with native speakers and understand what they are saying or what they want to deliver for us and to avoid the misunderstanding (Richards, Jack . and Rodgers, T, 1989). Thus, speaking can be the media to express the feeling or what we want to talk to the other people. In fact, many students in English Department cannot speak English fluently because of the interference by their first language (Bahasa).

Three research objectives of this research namely to know the influence of first language interference in students' speaking or speech production, and then to know the factor that influence the interference of first language in speaking.

\section{What is First Language Interference?}

At very young age, an individual begin acquiring at least one language, what linguists call first language (L1), producing it probably with little conscious effort or conscious perception (Saville-Troike, Muriel, 2006). It means first language or mother tongue are acquired in childhood period, first language that use in daily life and we influence when we speak with the first language. Dulay, et al in Bhela stated "Interference as the automatic transfer, due to habit, of the surface structure of the first language into the surface of the target language" (Dulay, H., Burt, M. \& Krashen, S, 1982). The interference of first language usually can occur when the speaker use second language such as in grammatical, lexical, or phonological. Relating to this study, first language interference in English speaking can occur in classroom through presentation and discussion.

\section{Type of First Language Interference}

Weinreich divides interference of first language into three types; phonological, grammatical and lexical interference (Weinreich, 2011).

\section{a. Phonological Aspect}

Phonology is the study of analyzing and talking about the harmony of sounds in language (Achmad., \& Abdullah, A, 2012). 
Table 1. Height, Frontness of Tongue Position and Muscle Tenseness according to Justice in Chaira (Chaira, S. 2015).

\begin{tabular}{|c|c|c|c|c|}
\hline \multirow[t]{2}{*}{ Height } & \multirow[t]{2}{*}{ Tenseness } & \multicolumn{2}{|c|}{ Frontness } & \multirow[b]{2}{*}{ Back } \\
\hline & & Front & Central & \\
\hline \multirow[t]{2}{*}{ High } & Tense & /i:/ & - & /u:/ \\
\hline & Lax & $/ \mathrm{I} /$ & - & $/ /$ \\
\hline \multirow[t]{2}{*}{ Mid } & Tense & e/ & $\mid a /$ & $/ \mathrm{o} /$ \\
\hline & Lax & $\mid \varepsilon /$ & $/ \partial / / \Lambda /$ & $/ \mathrm{s} /$ \\
\hline \multirow[t]{2}{*}{ Low } & Tense & - & - & - \\
\hline & Lax & /æ/ & - & /a/ \\
\hline
\end{tabular}

The table above shows about the vocal from tongue position when uttered the sounds that classify into two categories, they are height and frontness. Adittionally, vowels are also formed through muscle tension which requires muscles in the vocal tract to move and adjust based on the vowels created.

The table below is another additional table for vowels according to Yong in Chaira.

Table 2. English Vowel Sounds according to Yong in Chaira (Chaira, S. 2015).

\begin{tabular}{|c|c|c|c|c|c|c|}
\hline i: & I & $\varepsilon$ & $æ$ & $\mathrm{e}$ & aI & गI \\
\hline $\mathrm{a}:$ & $\mathrm{p}$ & ๑: & U & av & $\partial U$ & IO \\
\hline $\mathrm{u}:$ & $\Lambda$ & 3: & ə & eə & v & \\
\hline
\end{tabular}

Table 3. Indonesian Sounds according to Moeliono in Chaira (Chaira, S. 2015).

\begin{tabular}{lll}
\hline $\mathrm{I}$ & $\mathrm{u}$ \\
\hline $\mathrm{E}$ & $\mathrm{G}$ & $\mathrm{o}$ \\
\hline$\varepsilon$ & $\mathrm{a}$ & 0 \\
\hline
\end{tabular}

These vowel sounds are displayed in eight things whereas with vowels $[e]$ and $[\varepsilon]$ it is questionable whether they vary or not in articulation. Related arguments also happen with [o] and [o] where a few experts accept that those assortments of vowels speak to the same or a similar diaphone. Diphthong in Indonesia are /ai/, /au/, /oi/, dan /ei/, the examples in a word such as sepoi [sepoy], pulau [pulaw], pantai [pantai], and survey [survey] (Nafilah, I, Agustin, Y., \& Setiawati).

Table 4. Place and Manner of Articulation and Voicing Manner (Roach, P. 2009).

\begin{tabular}{|c|c|c|c|c|c|c|c|c|}
\hline & $\begin{array}{l}\text { Bila } \\
\text { bial }\end{array}$ & $\begin{array}{l}\text { Labio } \\
\text { dental }\end{array}$ & Dental & $\begin{array}{l}\text { Alveola } \\
r\end{array}$ & $\begin{array}{l}\text { Palato- } \\
\text { alveolar }\end{array}$ & Palatal & Velar & Glottal \\
\hline Stop/Plosive & $\mathrm{pb}$ & & & $\mathrm{td}$ & & & $\mathrm{kg}$ & \\
\hline Fricative & & $\mathrm{fv}$ & $\theta$ б & S Z & $\int 3$ & & & $\mathrm{~h}$ \\
\hline
\end{tabular}




\begin{tabular}{llllll}
\hline Affricate & & & t d & & \\
\hline Nasal & $\mathrm{m}$ & $\mathrm{n}$ & & $\mathrm{j}$ \\
& & & & \\
\hline Lateral & & $\mathrm{l}$ & & \\
& & & & \\
\hline Approximant & $\mathrm{w}$ & $\mathrm{r}$ & $\mathrm{j}$ & \\
& & & & \\
\hline
\end{tabular}

Table 5. Allophonic Variations according to Celce-Murcia, et al in Chaira (Chaira, S. 2015).

\begin{tabular}{|c|c|}
\hline Phonemes & Allophonic variation \\
\hline \multirow[t]{3}{*}{$/ \mathrm{p} /$} & [p $\left.\mathrm{p}^{\mathrm{h}}\right]$ (aspirated) \\
\hline & [p] (unaspirated) \\
\hline & {$\left[\mathrm{p}^{\circ}\right]$ (unaspirated) } \\
\hline \multirow[t]{3}{*}{$/ \mathrm{t} /$} & {$\left[\mathrm{t}^{\mathrm{h}}\right]$ (aspirated) } \\
\hline & [t] (unaspirated) \\
\hline & {$\left[\mathrm{t}^{\circ}\right]$ (unaspirated) } \\
\hline \multirow[t]{3}{*}{$/ \mathrm{k} /$} & {$\left[\mathrm{k}^{\mathrm{h}}\right]$ (aspirated) } \\
\hline & [k] (unaspirated) \\
\hline & 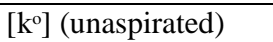 \\
\hline
\end{tabular}

While in Indonesian language the allophonic variation occurs in vowel. Teeuw stated that, several letter named allophonic variation in Indonesian language that are /i, e, a, o/ while Roi’s said if allophonic variation just occurs in /i/ and /a/ (Zanten, E, 1986). Therefore, in Indonesian language there are just /i, e, a, o/ in allophonic variation which does not include including the consonant in allophonic variation in Indonesian language.

Table 6. Indonesian consonant chart (Ruijgrok, 2008).

\begin{tabular}{|c|c|c|c|c|c|}
\hline & Labial & Alveolar & Palatal & Velar & Glottal \\
\hline Stop & $\mathbf{p}, \mathrm{b}$ & $\mathbf{t}, \mathrm{d}$ & c, J & $\mathbf{k}, \mathrm{g}$ & $?$ \\
\hline Fricative & & $\mathbf{S}$ & & & h \\
\hline Liquid & & $1 \mathrm{r}$ & & & \\
\hline Nasal & $\mathrm{m}$ & $\mathrm{n}$ & $\mathrm{n}$ & y & \\
\hline Glide & & $\mathrm{y}$ & & $\mathrm{w}$ & \\
\hline
\end{tabular}

*Bold alphabet are voiceless sounds

As there two fricatives in Indonesian, the fricatives /f, v, $\theta, \partial, \mathrm{z} /$ were failed to be found. 


\section{b. Grammatical Aspect}

Theory of grammar has no good or bad, right or wrong, true or false inherently but validated with the way in explaining and describing the phenomenon called language (Hervina, 2014). Grammatical interference is when the students identify the structure or morpheme of their mother tongue into the second or foreign language (Mahmud., \& Arifin, 2017). So, Indonesian and English also have the different way in grammar, both of these languages have unique grammatical or patterns to express the sentences in each language. In any case, both dialects moreover have a common design in sentence structure.

Weinreich decided grammatical interference in morphological and syntactical interference (Weinreich, 2011). According to Suwito through Ratih in her journal, the morphological interference happend when in the word formation absorb affixes that are prefix, suffix, and inserts from another language (Supriyanto, 2013). However, syntax is the study about the rules that produce an infinite number of grammatical in sentence (Jong Bok., $\&$ Sells, 2008). So, Bahasa and English have the different patterns to make the sentence. In Bahasa Indonesia, the defined word (primary) of a nominal sentence is put in the first position, but in English word (primary) of a nominal sentence is put in the second position. However, both languages also have a common pattern in sentence structure.

Generally, the students who learn second language have the grammatical error when they try to speak in English or make a sentence, they confuse how the pattern in English because so different with the Bahasa pattern or grammatical.

\section{c. Lexical Aspect}

Lexical interference is when one vocabulary interferes with another (Weinreich, 2011). Therefore, lexical is the vocabulary that is influenced by the first language that caused interference when the learners speaking in English as foreign language.

\section{The Nature of Speaking}

Clark states speaking is the basic of instrumental act, which means when people speak the words and sentences followed by the certain structure, which they produce as expression of their thoughts (Syamsudin, 2017). Speaking is producing the word utterance by utterance with the expression that the speakers want to deliver.

\section{The factors that is caused interference of first language}

According to Weinreich, there are some factors that caused the interference of first language: the first is speaker's bilingualism background that is people who use two languages which one of that language is a second language, absolutely they do some interference Linguists: Journal of Linguistics and Language Teaching Vol. 7, No. 1, July 2021 
because they can not dissapear some parts of their first language that can be interfere for their second languagedisloyalty to target language, the second is the limited vocabularies of target language mastered by a learner, the third is prestige and Style that is Saying new words in foreign language during a communication practice which prevailing words are dialects of both speaker and receivers is something different. Those new words use is expected to get a pride. The fourth is Disloyalty to target language that is the interference of first language that make the people or students apply their first language structure in speaking English which caused the error sentence or non sense sentence, (Weinreich, 2011).

\section{METHOD}

\section{Respondents}

The research method used in this research was descriptive qualitative research. The subject was sixth semester students in English Department class VI C that consists of 28 students and VI D that consists of 35 students. Interview session and observation sheet were conducted to analyze students' speech production. Then, researcher just took 8 students per class to make collecting data easier. Data collection technique and instrument of this research are observation checklist, observation sheet, interview, and documentation.

\section{Procedures}

Procedures of the research are: observing the students or students' documentary, analyzing the types of interference, categorizing or classifying kinds of phonological, grammatical, or lexical interference, interviewing and recording, transcribing the students' response in interviewing process, the data collected from the interview transcribed as transcription, and interpreting the data descriptively.

\section{Data Analysis}

The researcher joined in the classroom and observed the students interaction in classroom through their presentation and discussion that used English to find out what the interference of first language in linguistic aspect that students do when they speak in English. While, the researcher interviewed some students to obtain the answered about the factor that caused of interference of first language in speaking English via Whatsapp (voice note and chat). Then, the researcher took photos, images, or audio as the proof of the research. Data analysis techniques called Intercative Model (Miles, Matthew B and Huberman, A., 1994):

The researcher needs to make data reduction after collecting data, researcher made brief description of data obtained from many sources of data reduction. The 
researcher showed all the data found after all the data has been processed and then analysed them by finding and criticizing the interference of first language that occurred. The researcher then described the form of intervention and classified it. The researcher then correct the errors that are widely used in depth based on English. The researcher would be able to interpret the data after the presented data, draw interference and verification. The researcher identified and explained the interference forms that occurred. The researcher used data triangulation to make sure the data were valid through some data or different data such as observation, interview, and documentation.

\section{FINDINGS AND DISCUSSIONS}

The researcher discussed the findings that obtained in this chapter through observations and interview in English classes (6C and 6D) that did discussion in the classroom fully in English, and the researcher identify interference language that students did in their presentation in English class. In classes 6C and 6D the researcher obtained some data to observation checklist because it was before pandemic, however, pandemic of covid-19 that is spreading in Indonesia and entire of the world made the researcher did observation sheet and interview through online via whatsapp for several sample of students in $6 \mathrm{C}$ and $6 \mathrm{D}$ classes used is the documentation that are voice note and screenshoot of chat whatsapp with respondents.

\section{Observation}

\section{a. Observation Checklist}

Table 7. The Result of The Observation Checklist

\begin{tabular}{|c|c|c|c|c|}
\hline \multicolumn{3}{|c|}{ Types in second language that interference of first language } & \multicolumn{2}{|c|}{ Number of Respondends } \\
\hline & & & YES & NO \\
\hline \multirow[t]{4}{*}{ Phonological Aspects } & a) & $\begin{array}{l}\text { The English vowel } \\
\text { systems }\end{array}$ & 47 students & 16 students \\
\hline & b) & $\begin{array}{l}\text { The diphthongs in } \\
\text { phonology }\end{array}$ & 37 students & 26 students \\
\hline & c) & Consonant in English & 38 students & 25 students \\
\hline & d) & $\begin{array}{l}\text { Allophonic variation } \\
\text { in consonant }(\mathrm{p}, \mathrm{t}, \mathrm{k}) \text {. }\end{array}$ & 35 students & 28 students \\
\hline \multirow[t]{2}{*}{ Grammatical Aspects } & a) & $\begin{array}{l}\text { Morphological } \\
\text { Interference }\end{array}$ & 44 students & 19 students \\
\hline & b) & $\begin{array}{l}\text { Syntactical } \\
\text { Interference }\end{array}$ & 33 students & 30 students \\
\hline
\end{tabular}




\begin{tabular}{ll}
\hline Lexical Aspect & In speaking English occurs 38 students 25 students \\
& lexical interference when the \\
& subject uses or combines \\
& Indonesian language (Bahasa) \\
& and English when they speak in \\
& English
\end{tabular}

Therefore, from the table above we know if the students more often did interference of first language in speaking English is in phonological interference which is 47 students chosen vowel error, 37 students chosen diphthong error, 38 students chosen consonant error, and 35 students chosen allophonic variation in consonant $(\mathrm{p}, \mathrm{t}, \mathrm{k})$ error.

\section{b. Observation sheets on students' speech production}

The researcher observed students' speech production in two classes there are 6C and 6D (16 March, 2020) which the researcher took 16 samples from two classes for observation sheet ( 8 students per class) which the researcher asked about material course design book "Designing Language Couses: A Guide For Teachers" and asked them to read and explained it and the teacher also asked them such as "what do you know about course design?" and then the students answered that question with their English which did not depend on the book, the researcher also gave question-answer session about course design material. The table below explain about students' speech production and several data that explained if the students did interference of first language in phonological, grammatical, and lexical through the table:

Table 8. Frequency of Each Type of First Language Interference

\begin{tabular}{|c|c|c|c|c|}
\hline No & Type of Interference & Example & Frequency & Percentage \\
\hline \multirow[t]{7}{*}{1} & Phonological & \multirow{3}{*}{ Cultural (kalterel) } & \multirow{3}{*}{36} & \multirow{3}{*}{$28,6 \%$} \\
\hline & & & & \\
\hline & a. $\quad$ Vowels & & & \\
\hline & b. Diphthong & Values (veluus) & 15 & $11,9 \%$ \\
\hline & c. Consonants & Question (quescen) & 25 & $19,8 \%$ \\
\hline & $\begin{array}{l}\text { d. Allophonic variation in } \\
\text { consonant }(\mathrm{p}, \mathrm{t}, \mathrm{k})\end{array}$ & Material (mederial) & 7 & $5,5 \%$ \\
\hline & Total of Phonological & & & $65,8 \%$ \\
\hline \multirow[t]{2}{*}{2} & Interference & & & \\
\hline & Grammatical: & & & \\
\hline
\end{tabular}


1. Morphological

interference:
a) Singular-Plural
"These three
13
$10,3 \%$
Agreement
characteristic"

b) Subject-Verb

"to an understand

Agreement

of institutional and

4

$3,2 \%$

cultural contexts"

2. Syntactical Interference

"Achieve a certain

10

$7,9 \%$

a) Phrase and Sentence

goals".

b)Comparative

More easy write

$0,8 \%$

Adjective

objective

c) Possessive

I will answer you

$0,8 \%$

Adjective

question

d) Parallel structure

The content,

$1,6 \%$

objective, needs

assessment,

materials, and

evaluation are

working in progress.

3

\begin{tabular}{llll}
\hline $\begin{array}{l}\text { Total of Grammatical } \\
\text { Interference }\end{array}$ & \multicolumn{2}{c}{} & \\
\hline \multicolumn{1}{c}{ Lexical Interference } & $\begin{array}{l}\text { RPP is easily the } \\
\text { way of teaching and } \\
\text { learning process, } \\
\text { dengan adanya } \\
\end{array}$ & & \\
& RPP ini & \\
& & \\
\hline Total of Lexical Interference & & $\mathbf{9 , 5 \%}$ \\
\hline Total of all chategories & & $\mathbf{1 2 6}$ & $\mathbf{1 0 0 \%}$
\end{tabular}

\section{Percentage formula: $\mathrm{P}=\mathrm{F} / \mathrm{N}$ X $100 \%$}

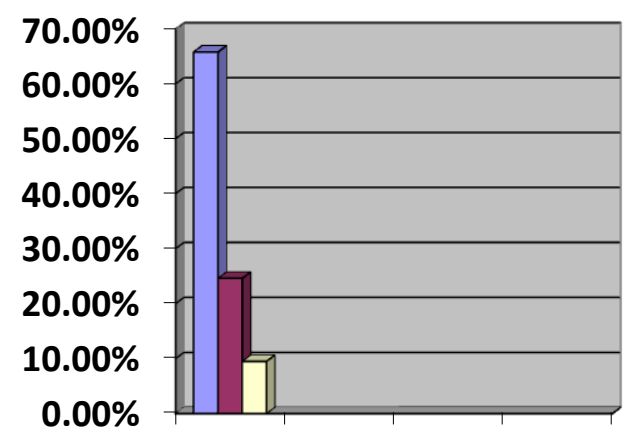

\begin{tabular}{|l|}
\hline Phonological \\
interference \\
$\square$ Grammatical \\
interference \\
$\square$ Lexical interference
\end{tabular}

Figure 1. Frequency of Each Type of First language Interference in general

Therefore, in phonological interference there is $65,8 \%$, in grammatical interference there is $24,6 \%$, and in lexical interference is $9,5 \%$. So, the dominant type that the students did Linguists: Journal of Linguistics and Language Teaching Vol. 7, No. 1, July 2021 
interference of first language in English speaking at sixth semester students in English department is phonological interference.

\section{Interview Session}

The researcher did interview session from 16 students in two class (6C and 6D) through whatsapp voice note and also chat, the researcher asked the student the questions and the students answered that. The questions about the interference of first language factors that students did. The factor why the students did interference of first language was lack of knowledge such as in pronunciation or grammatical based on the studens' answer: Maybe in the morphological to use suffix, prefix, and etc. I have problem when I do not understand the function in the sentence about the suffix, prefix, and etc and when I have lack knowledge about that because I really not interest with that grammatical because it that very bored so that is why I have many problems in grammatical. The next factor is Indonesian transfer. It means the students use their old habit which speaking in Indonesian or even using their own vernacular such as based on the studens' answer: I have problems in grammatical or structure because in Indonesia has different form in structure or grammar with English. The last factor is lack of vocabularies of second language that mastered by Students or Respondends such as based on the studens' answer: Of course, this is because of my lack of vocabulary mastering.

The researcher explained about several interference of first language that students did in phonological, grammatical, and lexical. In phonological, the students obtained obstacles in how to pronounce several word in English because the some vowel and consonant in English do not appear in Indonesia. And then, in Indonesia structure in phrase that is head word + modifier, while in English modifier + head word made students did grammatical error. It was because of interference of Indonesian structure. The last is lexical, the students who are learning second language that is English has lack of vocabulary that made them difficult to express what they want to say, and because of that, they combined between Indonesian and English when speaking in English.

The solving problem for phonology or pronunciation in English can be implemented by teachers, including by the use of Audio-lingual Method and Phonetic Method (Chaira, 2015). Using the audio-lingual method also support by Richard \& Rodger that is emphasizes the correct pronunciation because they teach the most accurate English sound for student (Richards \& Rodgers, 1986). In audio-lingual method also has several disadvantages, the students do not know the meaning about the words, and then the students cannot write the word because they just know how to pronounce it (Richards, J. \& Rodgers, T, 2001). In 
phonetic method has the advantage that is the students obtain the detail pronunciation or phonology of every single sound, this is supported by Matthew who recommends the students to use narrow phonetic transcription to avoid the interference or error (Matthew, 2005:38). However, the disadvantage of this method is the students cannot understand about the word that they mentioned but they just understand about how they pronounce that words. The suggestion to solve the problem in grammatical when speaking English are the students must assuming English is important language and need grammar to understand what the speaker said without misunderstanding (Hervina, 2014). The disadvantage when the students just know about the grammar is when do the communication the students just fail to apply their knowledge in grammatical (Long \& Doughty, 2009). Increasing the vocabulary through educational games can improve language education and help make language learning more entertaining (Donmus, 2010). However, According to Pham, 2007 there are disadvantages of using game, includes: Limited time, learners can be noisy, more playing than learning itself, students get bored if the games already familiar to them, and some learners who is teenagers think if the game is unnecessary. (Pham, 2007).

\section{CONCLUSION}

In conclusion, interference of first language in speaking English as foreign language in sixth semester students at English department occur in three types that are phonological, grammatical, and lexical. This results are also supported by Weinreich theory. In order, for the dominant type based on the students' point of view in see themselves in speaking English by using observation checklist, they admit if they do some interference when speaking English which is the dominant type is phonological interference. Similar to the result of students' speaking spech production (observation sheet) that researcher did, the dominant type of first language interference in students' speaking is phonological interference.

Based on the interview session there are several factors in interference of first language in foreign language; lack of knowledge, Indonesian transfer, lack of vocabularies of foreign language that mastered by students or respondents. Then, from this research, the readers will know about interference of first language that occurs in sixth semester students at English department in speaking English as foreign language. Beside that, the lecturers, teachers, and the other researchers will know if interference of first language can reduced by using of Audio-lingual Method and Phonetic Method for students, using narrow phonetic transcription to avoid the interference or error for students, motivating students if English is important language and need grammar to understand what the speaker said without misunderstanding, and using educational games for students. From this researh, the 
researcher hopes the government can provide the infrastructure facilities and recruits good teachers or lectures to teach English and design the syllabus.

\section{REFERENCES}

Achmad., \& Abdullah, A. (2012). Linguistik umum. Jakarta: Erlangga

Aini, L., Wibowo, A. \& Sriningsih, M. (2015). Linguistic analysis on Javanese language Selogudig-an dialect in Selogudig, Pajarakan, Probolinggo. Jurnal Ilmiah Bahasa dan Sastra ISSN: 23557083 Volume 2 Nomor 2 Desember 2015.

Bhela, B. (1999). Native language interference in learning a second language: Exploratory case studies of native language interference with target language usage. International Education Journal Vol 1, No 1, 1999. http://iej.cjb.net. Accessed on December 16th, 2019

Chaira, S. (2015). Interference of first language in pronunciation of English segmental sounds. English Education Journal (EEJ), 6(4), 469-483.

Donmus. (2010). The use of social networks in educational computer-game based foreign language learning. Procedia Social and Behavioral Sciences 9 (2010) 1497-1503. Available online at www.sciencedirect.com.

Dulay, H., Burt, M. \& Krashen, S. (1982). Language two. New York: Oxford.

Hervina, H. (2014). Grammatical errors in speaking made by the third year English Department students STKIP Abdi Pendidikan Payakumbuh. AL-Ta lim.

Jong Bok, K. \& Sells, P. (2008). English syntax: An introduction.

Justice, P. (2004). Relevant linguistics: An introduction to the structure and use of English for teachers. Stanford. CA: CSLI Publications.

Long, M. H., \& Doughty, C. J. (2009). The handbook of language teaching

Mahmud. \& Arifin, W. (2017). Interference: Its role in the second or foreign language mastery to Indonesian learners. ELT Perspective 5(1),May 2017.

Matthew, I. (2005). Errors in pronunciation of consonants by learners of English as a foreign language whose first languages are Indonesian, Gayo and Acehnese. Monash University Linguistics Papers, 3, 29- 44.

Miles., Matthew, B. \& Huberman, A. (1994). Qualitative data analysis: An expended sourcebook. California: Sage Publications.

Nafilah, I, Agustin, Y. \& Setiawati, S. Perbandingan gugus konsonan dan diftong dalam bahasa betwai dan bahasa indonesia.

Pham, T. H. (2007). The effects of games on optional English classes in Ben Tre primary school. HCM city: M.A thesis at the University of Social Sciences and Humanities, Vietnam National University- HCM City.

Richards, J.C. and Rodgers, T.S. (1986). Approaches and methods in language teaching. Cambridge: Cambridge University Press

Richards, J. \& Rodgers, T. (1989). Approaches and methods in language teaching. Cambridge: Cambridge University Press.

Richards, J. \& Rodgers, T. (2001). Approaches and methods in language teaching. Cambridge: Cambridge University Press.

Roach, P. (2009). English phonetics and phonology (a pratical course) fourth edition. Cambridge University, page. 97

Ruijgrok, B. (2008). Matters in Indonesian phonology. 
Saville, M. \& Troike. (2006). Introducing second language acquisition. New York: Cambridge university press.

Supriyanto, R. A. (2013). Grammatical interference from English into Indonesian language made by English native speakers in Salatiga. Register Journal, 6(2), 125-143.

Syamsudin, S. (2017). Communication strategies in speaking skill of EFL learners. English and Literature Journal, 2(1), 126-138.

Weinreich, U. (2011). Languages in contact: findings and problems (revised edition). Amsterdam/Philadelphia: John Benjamins Publishing Company.

Wood, W. \& Runger, D. (2015). Psychology of habit. Los Angeles, California: University of Southern California

Zanten, E. (1986). Allophonic variation in the production of Indonesian vowels. Journal of the Humanities and and Social Sciences of Southeast Asia. 